\title{
Management of African elephant populations in small fenced areas: Current practices, constraints and recommendations
}

\begin{tabular}{|c|c|}
\hline \multicolumn{2}{|c|}{$\begin{array}{l}\text { Authors: } \\
\text { S.A. Jeanetta Selier }{ }^{1,2} \\
\text { Rob Slotow }^{2,3} \\
\text { Dave Balfour }\end{array}$} \\
\hline \multicolumn{2}{|c|}{$\begin{array}{l}\text { Affiliations: } \\
{ }^{1} \text { South African National } \\
\text { Biodiversity Institute, } \\
\text { Pretoria, South Africa }\end{array}$} \\
\hline \multicolumn{2}{|c|}{$\begin{array}{l}{ }^{2} \text { School of Life Sciences, } \\
\text { University of KwaZulu-Natal, } \\
\text { South Africa }\end{array}$} \\
\hline \multicolumn{2}{|c|}{$\begin{array}{l}{ }^{3} \text { Department of Genetics, } \\
\text { Evolution and Environment, } \\
\text { University College, } \\
\text { United Kingdom }\end{array}$} \\
\hline \multicolumn{2}{|c|}{$\begin{array}{l}{ }^{4} \text { Centre for African } \\
\text { Conservation Ecology, } \\
\text { Nelson Mandela University, } \\
\text { South Africa }\end{array}$} \\
\hline \multicolumn{2}{|c|}{$\begin{array}{l}\text { Corresponding author: } \\
\text { Jeanetta Selier, } \\
\text { j.selier@sanbi.org.za }\end{array}$} \\
\hline \multicolumn{2}{|c|}{$\begin{array}{l}\text { How to cite this article: } \\
\text { Selier, S.A.J., Slotow, R. \& } \\
\text { Balfour, D., 2018, } \\
\text { 'Management of African } \\
\text { elephant populations in small } \\
\text { fenced areas: Current } \\
\text { practices, constraints and } \\
\text { recommendations', Bothalia } \\
\text { 48(2), a2414. https://doi. } \\
\text { org/10.4102/abc.v48i2.2414 }\end{array}$} \\
\hline \multicolumn{2}{|c|}{$\begin{array}{l}\text { Copyright: } \\
\text { C 2018. The Authors. } \\
\text { Licensee: AOSIS. This work } \\
\text { is licensed under the } \\
\text { Creative Commons } \\
\text { Attribution License. }\end{array}$} \\
\hline \multicolumn{2}{|l|}{ Read online: } \\
\hline 口itio & $\begin{array}{l}\text { Scan this QR } \\
\text { code with your } \\
\text { smart phone or } \\
\text { mobile device } \\
\text { to read online. }\end{array}$ \\
\hline
\end{tabular}

The history of elephant management in South Africa differs in a number of significant ways from that of range states to the north. This led to the country facing specific challenges in relation to the management of its elephant populations (Pretorius et al. 2018; Slotow et al. 2000, 2005). In most range states, although increasingly fragmented, elephant populations persist in unfenced landscapes including those in protected areas - where the main threats to their survival are poaching, habitat loss or transformation and human-elephant conflict (Thouless et al. 2016). In South Africa, elephant populations, the vast majority of which are in relatively small privately owned fenced areas, face an additional suite of threats. These include concerns over the genetic viability and loss of genetic heterogenity in small isolated populations (of the estimated 78 discrete elephant populations in the country, over 75\% have fewer than 100 individuals) (Pretorius et al. 2018) as well as concerns over the consequences of having fenced populations in relatively small areas (median area excluding Kruger National Park = 14200 ha; Elephant Specialist Advisory Group [ESAG] database 2015). The impact of elephants on vegetation in small fenced areas has resulted in the intensive management of these populations (such as through reducing the numbers or removing individuals, slowing population growth rates or excluding elephants from areas) aimed at reducing the rate of habitat impact and attempts by individual elephants to breach the fence (Carruthers et al. 2008; Delsink et al. 2013; Lagendijk et al. 2011; Slotow et al. 2005). The South African model for conserving elephants, although currently the exception, has a strong chance of becoming more common in Africa as the growing human footprint accelerates transformation of the natural landscape in Africa (Montesino Pouzols et al. 2014), and increases the opportunity for human-elephant conflict (Selier, Slotow \& Di Minin 2016). For this reason, it is useful to understand it better.

In 2006, the South African government convened a 'Science Round Table' - a think tank - which was mandated to provide advice to the state on managing the impact of elephants on vegetation and ecosystems. In light of the current ecological thinking, this group advised against the prevalent management rationale of managing (mainly culling or translocating individual elephants) elephant populations based on their numbers and crude habitat metrics (Scholes \& Mennell 2008). Deliberations arising from this new approach, which was based on a stronger recognition of the social structure and behavioural attributes of elephant populations, led to the publication of the National Norms and Standards for the Management of Elephants in South Africa in 2008 (Government Gazette no. 30833, 29 February 2008). These norms and standards currently guide the management of elephants in South Africa.

As elephant numbers have increased in South Africa over the past two decades, so too have the number of populations of elephant, and new insights and challenges are emerging in relation to their management. In part, these new insights and challenges are a consequence of the new approaches (such as preferentially using contraception [over culling]) to manage elephant population growth, and a consequence of advances that have been made in managing the impacts of elephant on vegetation and infrastructure. There is a need to review the norms and standards to update them in light of new knowledge and to enable them to appropriately regulate the new situations that are arising.

This special edition of the Bothalia: African Biodiversity and Conservation is aimed at providing a platform for documenting recent advances in research undertaken on the monitoring and management of elephant in a conservation context in South Africa. The papers included in this edition discuss contemporary methods for managing elephants, such as various forms of contraception, as well as problems experienced pertaining to implementing the norms and standards. They additionally provide recommendations from expert workshops held to address issues related to elephant management in South Africa. 
In the short communication, Garaï et al. (2018) provide feedback on the outcomes of an expert workshop on non-lethal elephant population control methods with recommendations to policymakers and for further research. Bertschinger et al. (2018) review the use of Porcine zona pellucida (PzP) vaccine as a means of immunocontraception of elephant cows, while Zitzer and Boult (2018) examine the behavioural implications of vasectomies on elephant bulls. Smaller reserves seldom have an intact bull hierarchical structure. In a number of these reserves, incidents with musth bulls have been reported, such as young bulls attacking rhinoceros or vehicles. While the introduction of mature bulls is recommended (Slotow et al. 2000), many reserves are apprehensive about the possible impact of big bulls on the vegetation structure of the reserve. Bertschinger and Leuders (2018), in their contribution, review the use of anti-gonadotrophin-releasing hormone $(\mathrm{GnRH})$ vaccines in African elephants to control androgen-related behaviours, and provide recommendations for the improved use of the vaccine.

Faecal hormone metabolite measurements are a widely used tool for monitoring reproductive function and response to stressors in wildlife and are commonly used to assess elephant stress (Ganswindt et al. 2003; Jachowski et al. 2012; Millspaugh et al. 2007; Poole et al. 1984; Viljoen 2009). Despite the many advantages, the delay between defecation, sample collection and further processing can influence steroid concentrations as bacterial enzymes alter the steroidal composition in faecal matter even post-defecation. Webber et al. (2018) investigate the rate of change of faecal glucocorticoid (fGCM), androgen (fAM) and progestogen (fPM) metabolite concentrations in male and female elephant faeces over time, as well as different drying regimes, and provide recommendations for sampling faecal material for these purposes from elephants in the wild.

Protected area managers commonly face conflicting conservation objectives. Elephants introduced into an area to increase tourism potential may compromise other conservation objectives. Rushworth et al. (2018) highlight the complexities of managing elephants in small areas, while at the same time seeking to conserve highly threatened vulture populations. Blackmore and Trouwborst (2018) explore the evolution of South African regulatory jurisprudence applicable to wildlife and analyse the norms and standards in relation to international and national legislation and common law as it applies to elephants. They find that the norms and standards are not applicable to free-roaming elephants that have no owner and, therefore, do not fulfil their primary objective of regulating the management of elephants across South Africa in a uniform manner. This limitation of the norms and standards requires attention during the revision process.

We anticipate that the collation and publication of this research in this special edition of the journal will inform the upcoming revision of the National Norms and Standards for Elephant Management. We further anticipate that, as similar challenges are faced in other countries, the contents of this special edition will be of interest to those involved in policy development as well as for the management of elephants in relatively small areas throughout their range in Africa.

\section{Acknowledgements Competing interests}

The authors declare that they have no financial or personal relationships that may have inappropriately influenced them in writing this article.

\section{Authors' contributions}

S.A.J.S. drafted the manuscript. R.S. and D.B. contributed to the manuscript.

\section{References}

Bertschinger, H.J., Delsink, A., Van Altena, J.J. \& Kirkpatrick, J.F., 2018, 'Porcine zona pellucida vaccine immunocontraception of African elephant (Loxodonta africana) cows: A review of 22 years of research', Bothalia 48(2), a2324. https://doi. org/10.4102/abc.v48i2.2324

Bertschinger, H.J. \& Lueders, I., 2018, 'Use of anti-gonadotropin-releasing hormone vaccines in African elephants (Loxodonta africana): A review', Bothalia 48(2), a2320. https://doi.org/10.4102/abc.v48i2.2320

Blackmore, A.C. \& Trouwborst, A., 2018, 'Who owns and is responsible for the elephant in the room? Management plans for free-roaming elephant in South Africa', Bothalia 48(2), a2271. https://doi.org/10.4102/abc.v48i2.2271

Carruthers, J., Boshoff, A., Slotow, R., Biggs, H.C., Avery, G. \& Matthews, W., 2008 'The elephant in South Africa: History and distribution', in J.R. Scholes \& K.G. Mennell (eds.), Elephant management: A scientific assessment for South Africa, pp. 23-83, WITS University Press, Johannesburg. https://doi. org/10.18772/22008034792.12

Delsink, A.K., Kirkpatrick, J., Van Altena, J., Bertschinger, H.J., Ferreira, S.M. \& Slotow, R., 2013, 'Lack of spatial and behavioral responses to immunocontraception application in African elephants (Loxodonta africana)', Journal of Zoo and Wildlife Medicine 44, S52-S74. https://doi.org/10.1638/1042-7260-44.4S.S52

Ganswindt, A., Palme, R., Heistermann, M., Borragan, S. \& Hodges, J., 2003, 'Noninvasive assessment of adrenocortical function in the male African elephant (Loxodonta africana) and its relation to musth', General and Comparative Endocrinology 134, 156-166. https://doi.org/10.1016/S0016-6480(03)00251-X

Garaï, M.E., Bates, L.A., Bertschinger, H., Delsink, A., Pretorius, Y., Selier, J. et al., 2018, 'Non-lethal elephant population control methods: Summary of the first workshop of the Elephant Specialist Advisory Group of South Africa', Bothalia 48(2), a2357. https://doi.org/10.4102/abc.v48i2.2357

Jachowski, D.S., Slotow, R. \& Millspaugh, J.J., 2012, ‘Physiological stress and refuge behavior by African elephants', PLoS One 7, e31818. https://doi.org/10.1371/ journal.pone.0031818

Lagendijk, D.G., Mackey, R.L., Page, B.R. \& Slotow, R., 2011, 'The effects of herbivory by a mega-and mesoherbivore on tree recruitment in sand forest, South Africa', PLoS One 6, e17983. https://doi.org/10.1371/journal.pone.0017983

Millspaugh, J.J., Burke, T., Van Dyk, G., Slotow, R., Washburn, B.E. \& Woods, R.J., 2007, 'Stress response of working African elephants to transportation and safar adventures', The Journal of Wildlife Management 71, 1257-1260. https://doi. org/10.2193/2006-015

Montesino Pouzols, F., Toivonen, T., Di Minin, E., Kukkala, A.S., Kullberg, P., Kuustera, J. et al., 2014, 'Global protected area expansion is compromised by projected landuse and parochialism', Nature 516, 383-386. https://doi.org/10.1038/ nature14032

Poole, J.H., Kasman, L., Ramsay, E. \& Lasley, B., 1984, 'Musth and urinary testosterone concentrations in the African elephant (Loxodonta africana)', Journal of Reproduction and Fertility 70, 255-260. https://doi.org/10.1530/jrf.0.0700255

Pretorius, Y., Garaï, M.E. \& Bates, L.A., 2018, 'The status of African elephant Loxodonta africana populations in South Africa', Oryx 1-7. https://doi. org/10.1017/S0030605317001454

Rushworth, I.A., Druce, D., Craigie, J. \& Coverdale, B., 2018, 'Vulnerability of vulture populations to elephant impact in KwaZulu-Natal', Bothalia 48(2), a2327. https:// doi.org/10.4102/abc.v48i2.2327

Scholes, R.J. \& Mennell, K., 2008, Elephant management: A scientific assessment for South Africa, Wits University Press, Johannesburg. https://doi.org/10.18772/22008034792

Selier, J., Slotow, R. \& Di Minin, E., 2016, 'The influence of socioeconomic factors on the densities of high-value cross-border species', Peerj 4, e2581. https://doi. org/10.7717/peerj. 2581 
Slotow, R., Garaï, M.E., Reilly, B., Page, B. \& Carr, R.D., 2005, 'Population dynamics of elephants re-introduced to small fenced reserves in South Africa', South African Journal of Wildlife Research 35, 23-32.

Slotow, R., van Dyk, G., Poole, J., Page, B. \& Klocke, A., 2000, 'Older bull elephants control young males', Nature 408, 425-426. https://doi.org/10.1038/35044191

Thouless, C.R., Dublin, H.T., Blanc, J.J., Skinner, D.P., Daniel, T.E., Taylor, R.D. et al., 2016, African elephant status report 2016. An update from the African Elephant Database, Occasional Paper Series of the IUCN Species Survival Commission, No. 60 IUCN / SSC Africa Elephant Specialist Group. IUCN, Gland Switzerland, vi $+309 \mathrm{pp}$
Viljoen, J.J., Ganswindt, A., du Toit, J.T. \& Langbauer Jr, W.R., 2009, 'Translocation stress and faecal glucocorticoid metabolite levels in free-ranging African savanna strephants', South African Journal of Wildlife Research 38, 146-152. https://doi. org/10.3957/0379-4369-38.2.146

Webber, J.T., Henley, M.D., Pretorius, Y., Somers, M.J. \& Ganswindt, A., 2018, 'Changes in African elephant (Loxodonta africana) faecal steriod concentrations postdefaecation', Bothalia 48(2), a2312. https://doi.org/10.4102/abc.v48i2.2312

Zitzer, H.R. \& Boult, V.L., 2018, 'Vasectomies of male African elephants as a population management tool: A case study', Bothalia 48(2), a2313. https://doi.org/10.4102/ abc.v48i2.2313 